\title{
Performance of Different Natural Antioxidant Compounds in Frying Oil
}

\author{
Buket Aydeniz and Emin Yilmaz \\ Department of Food Engineering, Faculty of Engineering, Çanakkale Onsekiz Mart University, \\ TR-17020 Çanakkale, Turkey \\ Received: February 5, 2015 \\ Accepted: October 22, 2015
}

\begin{abstract}
Summary
In this study, the natural green tea extract, purified lycopene, purified resveratrol and purified $\gamma$-oryzanol were added into peanut oil and their antioxidant performances were evaluated during frying. Moreover, the sensory properties of fried dough were evaluated to determine the consumption feasibility. All natural antioxidants led to significant increase in the stability of the oil samples. The ranges of measurements in the treatment groups were as follows: free acidity $0.1-2.9 \mathrm{~g}$ of oleic acid per $100 \mathrm{~g}$ of oil, conjugated dienes $0.01-0.40 \mathrm{~g}$ per $100 \mathrm{~g}$ of oil, total polar material $8.8-73.8 \mathrm{~g}$ per $100 \mathrm{~g}$ of oil, total phenolics $0.1-4.2 \mathrm{mg}$ of gallic acid equivalents per $100 \mathrm{~g}$ of oil, and antioxidant capacity $0.5-11.0$ $\mathrm{mM}$ of Trolox equivalents per $100 \mathrm{~g}$ of oil. The fatty acid and sterol compositions indicated that antioxidant supplementation could slow the oxidative degradation of unsaturated fatty acids and reduce trans-acid formation. Frying oil enriched with purified $\gamma$-oryzanol had higher sterol levels than the other enriched oil samples. The obtained quality of oil protection was in descending order: purified $\gamma$-oryzanol, green tea extract and purified lycopene.
\end{abstract}

Key words: frying oil, peanut oil, green tea extract, lycopene, resveratrol, $\gamma$-oryzanol

\section{Introduction}

Changes in human lifestyle, mainly due to industrialization, induced developments in food consumption, nutrition and health areas. Generally, sedentary lifestyle and factors like malnutrition, smoking, stress and city life necessitate a more healthy diet. Although the common trend is to reduce or limit the consumption of fried foods, their consumption level is gradually increasing owing to their properties such as being tasty, easily prepared and microbiologically safe (1). In order to minimize the negative effects and/or to maximize the positive health effects and to maintain the quality of the fried products, new techniques have been developed in recent years. Many researchers have suggested different techniques such as oil dilution, frying under modified atmosphere, hermetic frying, filtration, adsorbent treatment and addition of antioxidant additives into oil for the aforementioned purposes (2-5).
Antioxidants are chemical compounds that can be used to improve the oxidative stability of fats and oils by interrupting the free-radical mechanism of autoxidation. Synthetic antioxidants can readily retard lipid oxidation at room temperature, but they are easily degradable and can lose their activities at higher temperatures (5). Recently, phenolic extracts obtained from organic sources have gained popularity as natural food antioxidant supplements. In our previous study, we investigated the efficacy of phenolic extracts obtained from olive leaf, hazelnut leaf and hazelnut green leafy cover added into canola oil in actual frying conditions. It was shown that all frying oil samples with extracts had higher total phenolic content and antioxidant activity, and lower trans-fatty acid levels than those of oil containing no supplements (6).

Some agro-food industry by-products rich in polyphenols and antioxidant compounds could be preferably used as antioxidants instead of synthetics (7). Koh et al. (8) 
investigated the frying performance of palm-based medium- and long-chain triacylglycerol oil supplemented with tertiary butylhydroquinone (TBHQ) and oleoresin sage extract as antioxidants during frying for 5 consecutive days at $180^{\circ} \mathrm{C}$. The authors reported that antioxidant addition enhanced rancimat induction period compared with the oil without the added synthetic and natural antioxidants. Furthermore, the supplementation did not lead to any negative effects on the sensory characteristics (odour, taste, crispiness and overall acceptability) of potato chips.

Based on previous studies, we selected some plant extracts that contain chemically different antioxidant groups like catechins, stilbenes, carotenoids, phytosteryl ferulate mixtures and compared their activities under frying conditions. The plant materials utilized in this study were green tea (Camellia sinensis L.) extract, purified lycopene (Lycopersicon esculentum L.), purified resveratrol (Vitis vinifera L.) and purified $\gamma$-oryzanol (Oryza sativa L.). The peanut oil was chosen as frying medium because, compared to other types of vegetable oil, it has higher smoke point value $\left(229.4^{\circ} \mathrm{C}\right)$, which is an important criterion in the formation of low-fat and crispy surface foods and usage life of frying oil (9).

The aims of this study are to determine the effects of the extract obtained from green tea leaves, purified lycopene, which is an acyclic carotenoid found in tomato, purified resveratrol, which is a phytoalexin found in grapes, and purified $\gamma$-oryzanol, known as phytosterol ferulate ester mixture isolated from rice bran oil, on the control of thermal oxidation of peanut oil under the frying conditions and to compare their effects with synthetic antioxidant mixture. For this purpose, the antioxidant extracts mentioned above and synthetic antioxidants were added to peanut oil individually and dough samples were fried $5 \mathrm{~h}$ per day for seven consecutive days at $180{ }^{\circ} \mathrm{C}$.

\section{Materials and Methods}

\section{Materials}

Refined winterized peanut oil was kindly provided by Helvacizade Food Pharma \& Chemicals (Konya, Turkey). For dough preparation, white wheat flour (Kepez Flour, Çanakkale, Turkey), instant yeast (Dr. Oetker, İzmir, Turkey), and table salt (Billur salt, İzmir, Turkey) were purchased from local stores. Synthetic antioxidants butylated hydroxyanisole (BHA) and butylated hydroxytoluene (BHT) used in this study were kindly supplied by Kemin Food Technologies (Herentals, Belgium) and Vankim Chemical Ltd. (Istanbul, Turkey). Green tea leaves were from Caykur Tea Factory (Rize, Turkey). Purified $\gamma$-oryzanol (98\%, white crystalline powder) was provided by Oryza Oil \& Fat Chemical Co., Ltd. (Ichinomiya City, Japan). Purified resveratrol (ResVida, 99 \% trans-resveratrol, light grey powder) and purified lycopene (Redivivo, $10 \%$ lycopene finely dispersed in a matrix of modified food starch and glucose syrup with coating of corn starch) were provided by DSM Nutritional Products Ltd. (Basel, Switzerland). All chemicals used for the analyses were of analytical grade and purchased from Merck Co. (Darmstadt, Germany) and Sigma Chem. Co. (St. Louis,
MO, USA). Internal standards used in chromatographic analyses were purchased from Supelco (Bellefonte, PA, USA), Nu-Chek-Prep, Inc. (Elysian, MN, USA) and Sigma Chemical Co.

\section{Preparation and phenolic analysis of green tea extract}

Green tea extract was prepared according to Perva-Uzunalic et al. (10) with minor modifications. Green tea leaves were sorted, dried in a vacuum oven for $6 \mathrm{~h}$ at $40{ }^{\circ} \mathrm{C}$ and ground in a laboratory blender (Waring 7011S; Waring ${ }^{\circledR}$ Lab, Torrington, CT, USA). Then, the ground leaves were mixed with 20:1 (by volume per mass) extraction solvent (methanol/water 80:20, by volume) and extracted in an orbital shaker Unimax 2010 (Heidolph Instruments GmbH\&Co. KG, Schwabach, Germany) at 200 rpm and $45{ }^{\circ} \mathrm{C}$ for $2 \mathrm{~h}$. Finally, the mixture was centrifuged in a refrigerated centrifuge (Sigma 2-16 K; Sigma Laborzentrifugen $\mathrm{GmbH}$, Osterode am Hartz, Germany) at $1615 \times g$ and $4{ }^{\circ} \mathrm{C}$ for $10 \mathrm{~min}$. The supernatant was collected and the residue was re-extracted with $30 \mathrm{~mL}$ of extraction solvent. The solvent was then evaporated with rotary evaporator (Heidolph Instruments $\mathrm{GmbH \& Co}$. KG) under vacuum at $45^{\circ} \mathrm{C}$. The crude extract was kept frozen at $-18^{\circ} \mathrm{C}$ until usage.

The phenolic compounds in the green tea extract were determined according to the method described in ISO 14502-2:2005 (11). HPLC system consisting of degassing unit (Spectra system SCM 1000; Thermo Finnigan, Thermo Scientific, Waltham, MA, USA), gradient pump (Spectra system P4000; Thermo Finnigan), autosampler (Spectra system AS3000; Thermo Finnigan) and diode array detector (Spectra system UV6000LP; Thermo Finnigan), controlled by ChromQuest 4 software (Thermo Finnigan), was used for the phenolic compound analysis of the green tea extract. Separation was performed on a reversed-phase Luna ${ }^{\circledR} \mathrm{C} 18$ column $(250 \mathrm{~mm} \times 4.6 \mathrm{~mm}, 5$ $\mu \mathrm{m})$. Linear gradient elution programs with two mobile phases were used. The mobile phase A was acetic acid/ acetonitrile/water (3:9:88, by volume) and mobile phase B was acetic acid/acetonitrile/water (3:80:17, by volume), both containing $20 \mu \mathrm{g} / \mathrm{mL}$ of EDTA. The injection volume was $10 \mu \mathrm{L}$ and flow rate $1 \mathrm{~mL} / \mathrm{min}$ at $35^{\circ} \mathrm{C}$ column temperature. The phenolic compounds were characterized and quantified by comparing their retention times with those of commercially available standards. The results were expressed in $\mathrm{g}$ per $100 \mathrm{~g}$ of dry tea leaves.

\section{Measurement of total phenolic content}

The phenolics in the frying oil were first extracted with water/methanol (60:40, by volume) at $1: 1$ ratio for 2 $\mathrm{h}$. The extracts were centrifuged in a refrigerated centrifuge at $6797 \times g$ at $4{ }^{\circ} \mathrm{C}$ for $10 \mathrm{~min}$. The methanolic phase was separated and the residue was re-extracted by applying the same procedure. Then, the liquid phase was filtered through a $0.22-\mu \mathrm{m}$ membrane filter. The obtained extracts were used for the determination of total phenolics and also for the antioxidant capacity measurements of the frying oil.

The total phenolic content of the frying oil samples was measured with the Folin-Ciocalteu reagent and quantified with gallic acid standard curve $\left(R^{2}=0.999\right)$ as de- 
scribed by Chotimarkorn et al. (12). A volume of $250 \mu \mathrm{L}$ of phenolic extracts was mixed with $500 \mu \mathrm{L}$ of $0.2 \mathrm{M}$ Folin-Ciocalteu reagent and $6 \mathrm{~mL}$ of distilled water. Saturated sodium carbonate $(2 \mathrm{~mL})$ was added and then vigorously vortexed for $2 \mathrm{~min}$. Finally, the volume was set to $10 \mathrm{~mL}$ with distilled water. After incubation at room temperature for $2 \mathrm{~h}$, the absorbance of the solution was measured at $750 \mathrm{~nm}$ using an Agilent $8453 \mathrm{UV}$-Vis spectrophotometer (Waldbrann, Germany). The results were expressed in $\mathrm{mg}$ of gallic acid equivalents (GAE) per $100 \mathrm{~g}$ of oil.

\section{Measurement of antioxidant capacity}

The antioxidant capacity values of the synthetic and natural antioxidant extracts and the phenolic extracts obtained from the frying oil samples were measured by the Trolox equivalent antioxidant capacity (TEAC)/ABTS ${ }^{+}$ (2,2'-azinobis(3-ethylbenzothiazoline-6-sulfonic acid) diammonium salt) reference method using potassium persulfate as an oxidant according to Re et al. (13). The described method is based on the decolourization assay of the $\mathrm{ABTS}^{+}$free radical cation. The extent of decolourization is calculated as percentage reduction of the free radical cation absorbance at $734 \mathrm{~nm}$ and equated relative to the reactivity of Trolox as a standard compound, under the same conditions.

\section{Enrichment of peanut oil with the synthetic and natural antioxidants}

According to Codex Alimentarius Commission, synthetic antioxidants such as BHT and BHA are permitted at total concentrations of up to $200 \mathrm{ppm}$ (individually or combined) in edible fats and oils (1). Different masses of natural antioxidants were added to the peanut oil, calculated based on TEAC value of the oil with added antioxidant mixture ( $300 \mathrm{mg}$ of $\mathrm{BHA} / \mathrm{BHT}=1: 1$ by mass per 1500 $\mathrm{g}$ of oil) in order to reach $313.77 \mathrm{mM}$ of TEAC.

The calculated amounts were carefully weighed and then mixed with $100 \mathrm{~g}$ of oil at $100{ }^{\circ} \mathrm{C}$ and stirred in a high-performance homogenizer (Ultra Turrax, IKA-Werke GmbH\&Co. KG, Staufen, Germany) at $8000 \mathrm{rpm}$ for 7 min. Then, this stock oil was added to the bulk frying oil $(1.5 \mathrm{~kg})$ in the fryer. Before frying, $100 \mathrm{~mL}$ of oil samples were collected into amber-coloured capped glass bottles and kept frozen until analyses.

\section{Frying process}

In order to compare the influence of different oil samples on frying, a standard dough sample was prepered with the following ingredients: flour $62 \%$, water $37 \%$, and $0.5 \%$ of each instant yeast and table salt. Principally, every day during the study, all ingredients were mixed until dough was formed. The dough was left to ferment for $30 \mathrm{~min}$ at $40{ }^{\circ} \mathrm{C}$ (Ecocell Drying Oven, MMM Medcenter Einrichtungen $\mathrm{GmbH}$, Planegg, Germany), and then cut and rolled into 28-35 g patties. Home-type fryers (Arnica Z27A; Arnica, Istanbul, Turkey) were used for frying. The patties were fried for seven consecutive days in both control oil and oil samples with added synthetic antioxidant mixture (BHA/BHT), green tea extract, purified resveratrol, lycopene or purified $\gamma$-oryzanol. During the day, the oil was heated in open fryers for 5 to $5.5 \mathrm{~h}$ at $180{ }^{\circ} \mathrm{C}$.
The fryers were stopped during the night, and restarted the next day without any replenishment of fresh oil. Each day in each oil sample, two dough patties were fried for 10 min every half hour until a total of 20 patties were obtained per day. After each day, 100-mL oil samples were collected from each fryer and frozen in capped amber-coloured glass bottles until further analyses. The fried dough was placed into refrigerator bags, labelled and kept frozen until analyses. All frying treatments were replicated twice.

\section{Chemical characteristics of the oil samples}

The free fatty acid content of the oil samples was determined according to AOCS method Ca 5a-40 (14) by titrimetric technique with alcoholic potassium hydroxide and phenolphthalein indicator. The conjugated diene content was measured at $233 \mathrm{~nm}$ using an UV Mini 1240 spectrophotometer (Shimadzu Co, Tokyo, Japan) and 2,2,4-trimethylpentane (isooctane) as solvent by a method based on AOCS Ti 1a-64 (15). The total polar material was analyzed using a glass column filled with silica gel (12.5 g) and sea sand (2 g) in accordance with AOCS method Cd 20-91 (16). The total polar and non-polar compounds in oil were separated using the eluting solvents (petroleum ether/diethyl ether 87:13, by volume) drained through the column.

\section{Analysis of the fatty acid composition}

The fatty acid composition of the fresh peanut oil and frying oil samples at the end of the seventh day of frying was determined. The methyl esters of the fatty acids were prepared according to AOCS method Ce 2-66 (17) using methanolic $\mathrm{KOH} / \mathrm{MeOH}$, whereas the fatty acid composition of the oil samples was determined by the AOCS method Ce 1-62 (18). The quantification of the fatty acid methyl esters was performed with a Thermo Finnigan Trace $^{\mathrm{TM}}$ Ultra gas chromatograph equipped with HP 88 $(100 \mathrm{~m} \times 0.25 \mathrm{~mm}, 0.2 \mu \mathrm{m})$ capillary column. The carrier gas was helium at a flow rate of $20 \mathrm{~mL} / \mathrm{min}$ and the split ratio was 1:50. The injection volume was $1 \mu \mathrm{L}$. The oven temperature was programmed as follows: $150{ }^{\circ} \mathrm{C}$ for 2 min, with a programmed increase to $180{ }^{\circ} \mathrm{C}$ at a rate of 5 ${ }^{\circ} \mathrm{C} / \mathrm{min}$, then held for $8 \mathrm{~min}$, followed by an increase to $225^{\circ} \mathrm{C}$ at $10{ }^{\circ} \mathrm{C}$ and held at this temperature for $20 \mathrm{~min}$. The injector and detector temperatures were 250 and 300 ${ }^{\circ} \mathrm{C}$, respectively. The 37-component FAME mix (C4-C24; Supelco) and CLA standards (Nu-Chek-Prep, Inc.) were used for fatty acid determination.

\section{Analysis of sterol composition}

The phytosterol composition of the oil samples taken on the seventh day of frying was analyzed according to ISO 12228:1999 method (19) and the sterol composition of the fresh oil was also provided. The oil samples were first saponified with a solution of ethanolic potassium hydroxide by boiling under reflux. The residue (unsaponifiable matter) was dissolved in acetone and again dried under nitrogen. The sterol fractions from the unsaponifiable material were separated by thin-layer chromatography on silica gel $(20 \mathrm{~cm} \times 20 \mathrm{~cm}, 0.25$-mm layer thickness $)$ using hexane/diethyl ether (65:35, by volume) as developing 
solvent. Extracted fractions were injected by an autosampler into a PerkinElmer AutoSystem XL gas chromatograph (PerkinElmer, Waltham, MA, USA) equipped with flame ionization detector and an SE-54 $(30 \mathrm{~m} \times 0.32 \mathrm{~mm}$, $0.25 \mu \mathrm{m})$ column. Hydrogen was used as a carrier gas at a flow rate of $36 \mathrm{~cm} / \mathrm{s}$ with a 1:20 injector split. Injection volume was $1 \mu \mathrm{L}$. The injector and detector temperatures were $320^{\circ} \mathrm{C}$. The column oven initial temperature was $240{ }^{\circ} \mathrm{C}$ for $0.5 \mathrm{~min}$, increased at $5{ }^{\circ} \mathrm{C}$ per min to $255^{\circ} \mathrm{C}$ and held for $4 \mathrm{~min}$, then increased at $5^{\circ} \mathrm{C}$ per min to $310^{\circ} \mathrm{C}$ and held for $30 \mathrm{~min}$. GC control, data collection and integration were performed by Total Chrom Navigator v. 6.3.1 (PerkinElmer). The phytosterols were characterized by comparison of their retention times (relative to $5 \alpha$ -cholestane) to those of commercially available standards.

\section{Sensory analysis of the fried patties}

The patties fried on the fourth, fifth and sixth day in the control and oil samples enriched with extracts were taken and offered randomly for the consumer acceptance test (20). The sensory evaluation was performed by 100 panellists (48 females and 52 males aged 20-40, selected among food engineering students and academic staff). All fried patties were broken into four pieces, equilibrated to room temperature and then placed onto service plates coded with three-digit numbers. The panellists were provided with water and an expectoration cup to cleanse the palate between sensory evaluations. Samples from the three frying groups were tasted by all panellists. Tasting of each sample was randomly replicated twice by all panellists.

The sensory attributes (appearance, texture, taste/flavour, odour/aroma) of the fried patties were assessed by a five-point hedonic scale with anchor points ( 1 for 'dislike extremely' to 5 for 'like extremely'). The mean scores of the sensory attributes collected by the hedonic scale were calculated.

\section{Statistical analyses}

The whole frying experiment was replicated twice, and in each of the replicate samples, the analyses were completed at least twice. The statistical package program Minitab v. 16.1.1 (21) was used for all statistical analyses. Significant differences among the mean values of the sample measurements were determined by the two-way ANOVA with mean separation by Tukey's test at a $95 \%$ confidence level. Non-parametric Kruskal-Wallis test was applied for the consumer acceptance test results to determine the differences in the sensory properties of the fried patties. Dunn's test was used for mean separations. All results were presented as mean value \pm standard error or mean value \pm standard deviation.

\section{Results and Discussion}

\section{Free fatty acid content}

As expected, the free fatty acid content increased during frying (Table 1). Free fatty acid formation is attributed to hydrolysis and carboxyl group formation during frying (4). Oil samples supplemented with antioxidants had
Table 1. Free fatty acid content in control oil and oil supplemented with antioxidants

\begin{tabular}{cccc}
\hline \multirow{4}{*}{$t /$ day } & \multicolumn{3}{c}{$w /($ g oleic acid/100 g oil $)$} \\
\cline { 2 - 4 } & Control & BHA/BHT & GTE \\
\hline 0 & $(0.1 \pm 0.0)^{\mathrm{bC}}$ & $(0.2 \pm 0.0)^{\mathrm{abC}}$ & $(0.1 \pm 0.0)^{\mathrm{bF}}$ \\
1 & $(0.2 \pm 0.1)^{\mathrm{aC}}$ & $(0.4 \pm 0.1)^{\mathrm{aC}}$ & $(0.4 \pm 0.1)^{\mathrm{aEF}}$ \\
2 & $(0.4 \pm 0.1)^{\mathrm{aC}}$ & $(0.5 \pm 0.1)^{\mathrm{aC}}$ & $(0.5 \pm 0.1)^{\mathrm{aDEF}}$ \\
3 & $(0.7 \pm 0.2)^{\mathrm{aC}}$ & $(0.8 \pm 0.2)^{\mathrm{aBC}}$ & $(0.8 \pm 0.2)^{\mathrm{aDE}}$ \\
4 & $(1.1 \pm 0.2)^{\mathrm{aBC}}$ & $(1.1 \pm 0.2)^{\mathrm{aABC}}$ & $(0.9 \pm 0.02)^{\mathrm{aCC}}$ \\
5 & $(1.2 \pm 0.1)^{\mathrm{aBC}}$ & $(1.5 \pm 0.2)^{\mathrm{aAB}}$ & $(1.3 \pm 0.1)^{\mathrm{aBC}}$ \\
6 & $(1.7 \pm 0.3)^{\mathrm{aB}}$ & $(1.7 \pm 0.3)^{\mathrm{aA}}$ & $(1.5 \pm 0.1)^{\mathrm{aAB}}$ \\
7 & $(2.9 \pm 0.1)^{\mathrm{aA}}$ & $(1.9 \pm 0.3)^{\mathrm{bA}}$ & $(1.9 \pm 0.1)^{\mathrm{bA}}$ \\
\hline$t /$ day & $\mathrm{LYE}$ & $\mathrm{RSV}$ & $\mathrm{PGO}$ \\
\hline 0 & $(0.3 \pm 0.0)^{\mathrm{aE}}$ & $(0.2 \pm 0.0)^{\mathrm{abE}}$ & $(0.3 \pm 0.0)^{\mathrm{abD}}$ \\
1 & $(0.4 \pm 0.1)^{\mathrm{aDE}}$ & $(0.3 \pm 0.1)^{\mathrm{aE}}$ & $(0.4 \pm 0.1)^{\mathrm{aCD}}$ \\
2 & $(0.6 \pm 0.1)^{\mathrm{aDE}}$ & $(0.4 \pm 0.1)^{\mathrm{aDE}}$ & $(0.5 \pm 0.1)^{\mathrm{aCD}}$ \\
3 & $(0.8 \pm 0.1)^{\mathrm{aCD}}$ & $(0.7 \pm 0.2)^{\mathrm{aCD}}$ & $(0.9 \pm 0.1)^{\mathrm{aBCD}}$ \\
4 & $(1.0 \pm 0.1)^{\mathrm{aBC}}$ & $(0.9 \pm 0.2)^{\mathrm{aBC}}$ & $(1.0 \pm 0.1)^{\mathrm{aABCD}}$ \\
5 & $(1.2 \pm 0.1)^{\mathrm{aBC}}$ & $(1.2 \pm 0.2)^{\mathrm{aB}}$ & $(1.3 \pm 0.3)^{\mathrm{aABC}}$ \\
6 & $(1.5 \pm 0.1)^{\mathrm{aAB}}$ & $(1.3 \pm 0.2)^{\mathrm{aB}}$ & $(1.5 \pm 0.1)^{\mathrm{aAB}}$ \\
7 & $(1.7 \pm 0.2)^{\mathrm{bA}}$ & $(1.9 \pm 0.3)^{\mathrm{bA}}$ & $(1.9 \pm 0.3)^{\mathrm{bA}}$ \\
\hline
\end{tabular}

All results are mean value \pm standard error (S.E.)

Mean values followed by different lowercase letters in superscript represent significant differences among the measured properties $(\mathrm{p} \leq 0.05)$ in the frying groups

Mean values followed by different capital letters in superscript represent significant differences among the measured properties on a particular frying day $(\mathrm{p} \leq 0.05)$

$\mathrm{BHA} / \mathrm{BHT}=$ butylated hydroxyanisole/butylated hydroxytoluene mixture, GTE=green tea extract, LYE=purified lycopene,

$\mathrm{RSV}=$ purified resveratrol, $\mathrm{PGO}=$ purified $\gamma$-oryzanol

better stability and lower free fatty acid content than the control sample (Table 1). Frying experiments showed that when free fatty acid level exceeded $2 \mathrm{~g}$ per $100 \mathrm{~g}$ of oil, the fats became unwholesome and the oil required replacement (1). It was determined that free fatty acid content of the oil with added antioxidants remained below the permitted level at the end of the seventh frying day, but it was not statistically significantly different. Natural antioxidants kept the free fatty acid of the oil samples at similar levels as the synthetic antioxidants (Table 1).

\section{Conjugated dienes in frying oil samples}

The conjugated dienes/trienes are primary oxidation products and they serve as reliable indicators for monitoring the oxidative stability of the frying oil. Their mass fractions in the oil samples throughout the seven consecutive frying days are listed in Table 2 . As it is seen, the conjugated diene contents show a pattern similar to that of the free fatty acids during 35-hour batch frying. Their mass fractions ( $0.16-0.30 \mathrm{~g}$ per $100 \mathrm{~g}$ of oil) in the oil samples supplemented with antioxidants were lower than in the control sample $(0.40 \mathrm{~g}$ per $100 \mathrm{~g}$ of oil $)$ at the end of the seventh day of frying. It was also determined that the lycopene extract was more effective than the other plant extracts in controlling the free fatty acid and conjugated 
Table 2. Mass fraction of conjugated dienes in control and oil supplemented with antioxidants

\begin{tabular}{cccc}
\hline \multirow{3}{*}{$t /$ day } & \multicolumn{3}{c}{$w /(\mathrm{g} / 100 \mathrm{~g}$ oil $)$} \\
\cline { 2 - 4 } & Control & $\mathrm{BHA} / \mathrm{BHT}$ & $\mathrm{GTE}$ \\
\hline 0 & $(0.01 \pm 0.00)^{\mathrm{bD}}$ & $(0.01 \pm 0.00)^{\mathrm{bD}}$ & $(0.01 \pm 0.00)^{\mathrm{bD}}$ \\
1 & $(0.09 \pm 0.01)^{\mathrm{bCD}}$ & $(0.06 \pm 0.04)^{\mathrm{bCD}}$ & $(0.02 \pm 0.01)^{\mathrm{bCD}}$ \\
2 & $(0.09 \pm 0.01)^{\mathrm{bCD}}$ & $(0.07 \pm 0.01)^{\mathrm{bBCD}}$ & $(0.07 \pm 0.03)^{\mathrm{bBCD}}$ \\
3 & $(0.12 \pm 0.1)^{\mathrm{abBCD}}$ & $(0.09 \pm 0.01)^{\mathrm{bBCD}}$ & $(0.07 \pm 0.01)^{\mathrm{bBCD}}$ \\
4 & $(0.15 \pm 0.1)^{\mathrm{abBCD}}$ & $(0.10 \pm 0.01)^{\mathrm{abBCD}}$ & $(0.10 \pm 0.01)^{\mathrm{abABC}}$ \\
5 & $(0.20 \pm 0.1)^{\mathrm{abBC}}$ & $(0.15 \pm 0.02)^{\mathrm{bBC}}$ & $(0.12 \pm 0.01)^{\mathrm{bAB}}$ \\
6 & $(0.30 \pm 0.2)^{\mathrm{aAB}}$ & $(0.19 \pm 0.02)^{\mathrm{abAB}}$ & $(0.13 \pm 0.01)^{\mathrm{bAB}}$ \\
7 & $(0.40 \pm 01)^{\mathrm{aA}}$ & $(0.27 \pm 0.02)^{\mathrm{abA}}$ & $(0.18 \pm 0.02)^{\mathrm{bA}}$ \\
\hline$t / \mathrm{day}$ & $\mathrm{LYE}$ & $\mathrm{RSV}$ & $\mathrm{PGO}$ \\
\hline 0 & $(0.02 \pm 0.01)^{\mathrm{bC}}$ & $(0.02 \pm 0.01)^{\mathrm{bC}}$ & $(0.11 \pm 0.04)^{\mathrm{aC}}$ \\
1 & $(0.03 \pm 0.01)^{\mathrm{bC}}$ & $(0.04 \pm 0.01)^{\mathrm{bC}}$ & $(0.14 \pm 0.01)^{\mathrm{aBC}}$ \\
2 & $(0.05 \pm 0.02)^{\mathrm{bBC}}$ & $(0.11 \pm 0.03)^{\mathrm{abBC}}$ & $(0.17 \pm 0.001)^{\mathrm{aBC}}$ \\
3 & $(0.07 \pm 0.04)^{\mathrm{bBC}}$ & $(0.12 \pm 0.02)^{\mathrm{abBC}}$ & $(0.18 \pm 0.03)^{\mathrm{aBC}}$ \\
4 & $(0.07 \pm 0.02)^{\mathrm{bBC}}$ & $(0.19 \pm 0.03)^{\mathrm{abAB}}$ & $(0.22 \pm 0.04)^{\mathrm{aAB}}$ \\
5 & $(0.11 \pm 0.02)^{\mathrm{bB}}$ & $(0.19 \pm 0.04)^{\mathrm{abAB}}$ & $(0.24 \pm 0.05)^{\mathrm{aAB}}$ \\
6 & $(0.12 \pm 0.02)^{\mathrm{bAB}}$ & $(0.20 \pm 0.06)^{\mathrm{abAB}}$ & $(0.25 \pm 0.06)^{\mathrm{abAB}}$ \\
7 & $(0.16 \pm 0.03)^{\mathrm{bA}}$ & $(0.27 \pm 0.06)^{\mathrm{abA}}$ & $(0.30 \pm 0.07)^{\mathrm{abA}}$ \\
\hline
\end{tabular}

All results are mean value \pm standard error (S.E.)

Mean values followed by different lowercase letters in superscript represent significant differences among the measured properties $(\mathrm{p} \leq 0.05)$ in the frying groups

Mean values followed by different capital letters in superscript represent significant differences among the measured properties on a particular frying day $(\mathrm{p} \leq 0.05)$

BHA/BHT=butylated hydroxyanisole/butylated hydroxytoluene mixture, GTE=green tea extract, LYE=purified lycopene,

$\mathrm{RSV}=$ purified resveratrol, $\mathrm{PGO}=$ purified $\gamma$-oryzanol

diene levels. However, there is no legal arrangement related to the upper limit of conjugated diene/triene content of frying oil. A number of researchers indicated that conjugated diene and triene contents changed with frying time and temperature, oil composition, etc. $(6,22,23)$. Abdulkarim et al. (24) reported that conjugated diene content was markedly affected by fatty acid composition of the oil and that diene and triene levels in the oil increased with increasing level of unsaturated fatty acids.

\section{Mass fractions of total polar material}

Polar materials are polymerized and oxidized triacylglycerol dimers, including a wide class of products of pyrolysis, oxidation, condensation and hydrolysis. The amount of total polar compounds in frying oil is an important factor to measure the oxidative degradation, and to determine the usage life and quality of frying oil. In addition, it affects the absorption of fat by fried food products. In this study, the total polar material (TPM) values were found to increase steadily in all treatment groups. Interestingly, the oil samples supplemented with natural antioxidant extracts had more TPM (Table 3). The reason for this is possibly due to the natural polar characteristics of the supplemented materials. As observed in Table 3, on the first day of supplementation, which is the day before
Table 3. Content of total polar material in control and oil supplemented with antioxidants

\begin{tabular}{|c|c|c|c|}
\hline \multirow{2}{*}{$t /$ day } & \multicolumn{3}{|c|}{$w /(\mathrm{g} / 100 \mathrm{~g}$ oil $)$} \\
\hline & Control & BHA/BHT & GTE \\
\hline 0 & $(11.1 \pm 1.3)^{\mathrm{abC}}$ & $(14.6 \pm 3.4)^{\mathrm{aE}}$ & $(10.7 \pm 2.4)^{\mathrm{abE}}$ \\
\hline 1 & $(15.0 \pm 1.2)^{\mathrm{bBC}}$ & $(20.5 \pm 2.7)^{\mathrm{abDE}}$ & $(14.9 \pm 2.6)^{\mathrm{bE}}$ \\
\hline 2 & $(15.6 \pm 0.1)^{\mathrm{CBC}}$ & $(27.9 \pm 0.8)^{\mathrm{abCD}}$ & $(23.2 \pm 0.5)^{\mathrm{bcDE}}$ \\
\hline 3 & $(22.9 \pm 1.8)^{\mathrm{cABC}}$ & $(33.9 \pm 4.7)^{\mathrm{abBCD}}$ & $(33.5 \pm 2.2)^{\mathrm{abCD}}$ \\
\hline 4 & $(25.3 \pm 1.4)^{\mathrm{bABC}}$ & $(42.1 \pm 2.9)^{\mathrm{aBC}}$ & $(41.9 \pm 2.5)^{\mathrm{aBC}}$ \\
\hline 5 & $(33.9 \pm 2.1)^{\mathrm{cAB}}$ & $(48.5 \pm 3.7)^{\mathrm{abAB}}$ & $(47.6 \pm 3.2)^{\mathrm{abABC}}$ \\
\hline 6 & $(42.1 \pm 1.8)^{\mathrm{CAB}}$ & $(53.9 \pm 3.6)^{\mathrm{abAB}}$ & $(56.3 \pm 3.8)^{\mathrm{abAB}}$ \\
\hline 7 & $(48.1 \pm 1.6)^{\mathrm{cA}}$ & $(63.1 \pm 5.8)^{\mathrm{abA}}$ & $(61.4 \pm 5.6)^{\mathrm{abA}}$ \\
\hline t/day & LYE & RSV & PGO \\
\hline 0 & $(8.8 \pm 0.6)^{\mathrm{bD}}$ & $(14.8 \pm 3.8)^{\mathrm{aE}}$ & $(13.3 \pm 2.1)^{\mathrm{aF}}$ \\
\hline 1 & $(17.3 \pm 2.1)^{\mathrm{abCD}}$ & $(24.5 \pm 7.1)^{\mathrm{a} \mathrm{DE}}$ & $(18.4 \pm 2.8)^{\mathrm{abEF}}$ \\
\hline 2 & $(26.4 \pm 1.2)^{\mathrm{abcBC}}$ & $(37.1 \pm 4.3)^{\mathrm{aCD}}$ & $(22.7 \pm 1.1)^{\mathrm{bCDEF}}$ \\
\hline 3 & $(33.5 \pm 5.3)^{\mathrm{ab} A B C}$ & $(38.3 \pm 8.1)^{\mathrm{aCD}}$ & $(29.3 \pm 1.1)^{\mathrm{bcCDE}}$ \\
\hline 4 & $(36.7 \pm 1.9)^{\mathrm{abAB}}$ & $(43.2 \pm 3.3)^{\mathrm{aBCD}}$ & $(36.8 \pm 2.8)^{\mathrm{abBCD}}$ \\
\hline 5 & $(53.5 \pm 2.8)^{\mathrm{aA}}$ & $(52.3 \pm 5.5)^{\mathrm{aABC}}$ & $(43.4 \pm 3.5)^{\mathrm{bcABC}}$ \\
\hline 6 & $(54.6 \pm 9.6)^{\mathrm{abA}}$ & $(67.9 \pm 4.5)^{\mathrm{aAB}}$ & $(50.5 \pm 1.7)^{\mathrm{bcAB}}$ \\
\hline 7 & $(57.2 \pm 2.4)^{\mathrm{bcA}}$ & $(73.8 \pm 12.4)^{\mathrm{aA}}$ & $(58.3 \pm 2.5)^{\mathrm{bcA}}$ \\
\hline
\end{tabular}

All results are mean value \pm standard error (S.E.)

Mean values followed by different lowercase letters in superscript represent significant differences among the measured properties $(\mathrm{p} \leq 0.05)$ in the frying groups

Mean values followed by different capital letters in superscript represent significant differences among the measured properties on a particular frying day $(\mathrm{p} \leq 0.05)$

BHA/BHT=butylated hydroxyanisole/butylated hydroxytoluene mixture, GTE=green tea extract, LYE=purified lycopene, $\mathrm{RSV}=$ purified resveratrol, $\mathrm{PGO}=$ purified $\gamma$-oryzanol

the beginning of frying, higher TPM values were measured in the oil with supplements, compared to the control group. Clearly, some compounds with polar characteristics exist in the plant extracts used to enrich the oil, which is confirmed by the data.

The minimum increase of the TPM mass fraction was detected in the oil samples supplemented with lycopene at the end of frying, owing to the nature of lycopene, which is a non-polar compound. Literature reports that frying time and temperature induced the formation of total polar material (5). Lee et al. (25) investigated the effect of different mass fractions $(5,15$ and $25 \%)$ of spinach powder as a natural antioxidant on soybean oil frying performance. The researchers reported a decrease of conjugated diene and polar material contents and an increase of the oxidative stability of the oil during $20 \mathrm{~h}$ of frying at $160{ }^{\circ} \mathrm{C}$. Kochhar (1) stated that the TPM contents of groundnut oil and palm olein increased with frying time and the oil samples became unusable after 20 and $40 \mathrm{~h}$, respectively. According to the Turkish Official Notification of the Control Criteria of Frying Fats/Oils (26), when the TPM content in frying oil exceeds $25 \mathrm{~g}$ per $100 \mathrm{~g}$ of oil, it should be discarded. In the present study, it was determined that enriched oil samples have higher total polar material content than the control oil sample during frying days. The TPM content of the samples containing green 
tea extract and purified $\gamma$-oryzanol exceeded the legal limit after the second day of frying (Table 3). Since the added extracts are chemically polar in their nature, the increase in TPM might be due to the added compounds, and not the consequence of lipid oxidation.

\section{Total phenolic content}

The green tea extract contained (in g): epigallocatechin gallate 7.410, epigallocatechin 3.841, epicatechin gallate 1.224 , epicatechin 0.721 , catechin 0.036 , caffeine 1.704 , theaflavin 0.003 , theaflavin digallate 0.002 , theaflavin 3-monogallate 0.002 , theaflavin 3-monogallate 0.004, gallic acid 0.026 per $100 \mathrm{~g}$ of dry tea leaves. These results are in agreement with the literature values $(27,28)$.

The total phenolic contents of the frying oil samples are shown in Table 4. Addition of the natural extracts caused a distinctive and statistically significant $(\mathrm{p} \leq 0.05)$ increase in the total phenolic values of the oil samples. The total phenolic content of oil samples decreased at the end of the seventh day of frying in the following order: purified $\gamma$-oryzanol>green tea extract $>$ purified lycopene $>$ purified resveratrol, even though it could not be detected in the control and in the samples with added synthetic antioxidants. This variation may be due to the different

Table 4. Total phenolic content in control and oil supplemented with antioxidants

\begin{tabular}{cccc}
\hline \multirow{3}{*}{$t /$ day } & \multicolumn{3}{c}{$w /(\mathrm{mg}$ GAE/100 g oil $)$} \\
\cline { 2 - 4 } & Control & BHA/BHT & GTE \\
\hline 0 & $(1.3 \pm 0.6)^{\mathrm{cA}}$ & $(1.7 \pm 0.1)^{\mathrm{bcA}}$ & $(4.2 \pm 1.0)^{\mathrm{aA}}$ \\
1 & $(1.1 \pm 0.2)^{\mathrm{bAB}}$ & $(1.1 \pm 0.4)^{\mathrm{bA}}$ & $(2.6 \pm 0.3)^{\mathrm{aAB}}$ \\
2 & $(0.9 \pm 0.2)^{\mathrm{bcBC}}$ & $(0.5 \pm 0.3)^{\mathrm{cAB}}$ & $(2.1 \pm 0.2)^{\mathrm{aAB}}$ \\
3 & $(0.6 \pm 0.1)^{\mathrm{bcBC}}$ & $(0.3 \pm 0.2)^{\mathrm{cAB}}$ & $(1.3 \pm 0.4)^{\mathrm{abBC}}$ \\
4 & $(0.5 \pm 0.1)^{\mathrm{bCBC}}$ & $(0.20 \pm 0.06)^{\mathrm{cBC}}$ & $(1.0 \pm 0.1)^{\mathrm{abC}}$ \\
5 & $(0.4 \pm 0.1)^{\mathrm{bcBC}}$ & $(0.1 \pm 0.0)^{\mathrm{cC}}$ & $(0.8 \pm 0.1)^{\mathrm{abC}}$ \\
6 & $(0.2 \pm 0.1)^{\mathrm{bcC}}$ & $(0.1 \pm 0.0)^{\mathrm{cC}}$ & $(0.7 \pm 0.1)^{\mathrm{abC}}$ \\
7 & n.d. & n.d. & $(0.5 \pm 0.1)^{\mathrm{abC}}$ \\
\hline$t /$ day & LYE & RSV & PGO \\
\hline 0 & $(1.7 \pm 0.4)^{\mathrm{bCA}}$ & $(2.7 \pm 0.2)^{\mathrm{abA}}$ & $(2.7 \pm 0.2)^{\mathrm{abA}}$ \\
1 & $(1.4 \pm 0.6)^{\mathrm{abA}}$ & $(2.1 \pm 0.3)^{\mathrm{aAB}}$ & $(2.3 \pm 0.1)^{\mathrm{aAB}}$ \\
2 & $(1.2 \pm 0.3)^{\mathrm{abA}}$ & $(1.7 \pm 0.3)^{\mathrm{abABC}}$ & $(2.0 \pm 0.1)^{\mathrm{aAB}}$ \\
3 & $(1.0 \pm 0.3)^{\mathrm{abAB}}$ & $(1.0 \pm 0.1)^{\mathrm{abBC}}$ & $(1.9 \pm 0.1)^{\mathrm{aABC}}$ \\
4 & $(0.9 \pm 0.2)^{\mathrm{abAB}}$ & $(0.8 \pm 0.2)^{\mathrm{abC}}$ & $(1.6 \pm 0.1)^{\mathrm{abC}}$ \\
5 & $(0.8 \pm 0.2)^{\mathrm{abAB}}$ & $(0.7 \pm 0.2)^{\mathrm{abC}}$ & $(1.4 \pm 0.1)^{\mathrm{aBC}}$ \\
6 & $(0.5 \pm 0.1)^{\mathrm{abB}}$ & $(0.6 \pm 0.2)^{\mathrm{abC}}$ & $(1.1 \pm 0.2)^{\mathrm{aBC}}$ \\
7 & $(0.4 \pm 0.1)^{\mathrm{abB}}$ & $(0.3 \pm 0.1)^{\mathrm{bC}}$ & $(0.8 \pm 0.3)^{\mathrm{aCC}}$ \\
\hline
\end{tabular}

All results are mean value \pm standard error (S.E.)

Mean values followed by different lowercase letters in superscript represent significant differences among the measured properties $(\mathrm{p} \leq 0.05)$ in the frying groups

Mean values followed by different capital letters in superscript represent significant differences among the measured properties on a particular frying day $(\mathrm{p} \leq 0.05)$

BHA/BHT=butylated hydroxyanisole/butylated hydroxytoluene mixture, GTE=green tea extract, $\mathrm{LYE}=$ purified lycopene, RSV=purified resveratrol, $P G O=$ purified $\gamma$-oryzanol, n.d. $=$ not detected solubility (polarity) and stability characteristics of the added extracts. The recovery rates of phenolics from supplemented oil samples at the end of the seventh day of frying were calculated as follows (in \%): green tea extract 13.1, lycopene 25.9, resveratrol 13.4 and purified $\gamma$-oryzanol 30. The ability of sesame extracts to enhance the oxidative stability of common consumption vegetable oil under thermal conditions was examined by Konsoula and Liakopoulou-Kyriakides (29). The researchers notified that sesame seed extract plays an important role in the enhancement of the total phenolic content and antioxidant capacity, as well as in the reduction of peroxide formation.

\section{Antioxidant capacity of supplemented oil}

Before frying, the oil samples in all frying groups except control group were supplemented with the antioxidants. The addition levels of these antioxidants (Table 5) were determined based on TEAC value (313.77 $\mathrm{mM}$ of TEAC) of the mixture of synthetic antioxidants (BHA/ $\mathrm{BHT}=1: 1$, by mass) at $300 \mathrm{mg}$ per $1500 \mathrm{~g}$ of oil. It was observed that antioxidant capacity values measured in the oil samples on the day zero (before the beginning of frying) were different from each other and this difference was statistically significant, although they were supplemented with equivalent amount of synthetic and natural antioxidants. The difference of the antioxidant capacity values on day zero can be explained by the following reasons: firstly, all antioxidant capacities were measured in the samples with phenolic extracts obtained from peanut oil samples instead of synthetic and natural antioxidant extracts. It must be kept in mind that the added extracts must have different solubility characteristics when added to the oil. Furthermore, all antioxidants must have different dissolution in oil, hence different recovery rate by the extraction protocol was applied. This can also explain why their addition caused different chemical reactions that prevent the oxidation of the oil during frying. In addition, it is believed that the recovery rate and the extraction conditions may affect the antioxidant capacity of peanut oil.

Table 5. The antioxidant capacity and mass of synthetic and natural antioxidants added to oil samples

\begin{tabular}{|c|c|c|}
\hline & Antioxidant capacity & \multirow{2}{*}{$\begin{array}{c}m / g \\
\text { (equivalent to } \\
313.77 \mathrm{mM} \text { TEAC) }\end{array}$} \\
\hline & mM TEAC/g extract & \\
\hline $\begin{array}{l}\text { BHA/BHT } \\
\text { (1:1 by mass) }\end{array}$ & $(1045.9 \pm 11.2)^{\mathrm{C}}$ & $0.30^{\mathrm{C}}$ \\
\hline GTE & $(1442.2 \pm 11.6)^{\mathrm{B}}$ & $0.21^{\mathrm{D}}$ \\
\hline LYE & $(76.3 \pm 4.7)^{\mathrm{D}}$ & $4.10^{\mathrm{B}}$ \\
\hline RSV & $(6251.9 \pm 14.6)^{\mathrm{A}}$ & $0.05^{\mathrm{E}}$ \\
\hline PGO & $(72.6 \pm 3.9)^{\mathrm{D}}$ & $4.32^{\mathrm{A}}$ \\
\hline
\end{tabular}

All results are mean value \pm standard error (S.E.)

Mean values followed by different letters in superscript represent significant differences among all measured properties $(p \leq 0.05)$ in the synthetic and natural antioxidant extracts BHA/BHT=butylated hydroxyanisole/butylated hydroxytoluene mixture, GTE=green tea extract, LYE=purified lycopene, $\mathrm{RSV}=$ purified resveratrol, $\mathrm{PGO}=$ purified $\gamma$-oryzanol 
Generally, the antioxidant capacity of the oil samples decreased with the increase of frying time (Table 6). Even though the oil samples containing synthetic antioxidants and the control group exhibited similar results, no antioxidant activity was detected in both groups after the fifth frying day. It is obvious that $\gamma$-oryzanol, which has high thermal stability, is the most efficient antioxidant in frying oil. There was statistically significant difference between the oil samples supplemented with $\gamma$-oryzanol and other natural antioxidants at the end of the seventh day of frying. Although green tea extract and resveratrol had higher antioxidant capacity than the other extracts in fresh oil, they had lower remaining antioxidant activity than purified $\gamma$-oryzanol and lycopene at the end of frying (Table 6). It was demonstrated that extracts have different solubility and polarity characteristics in oil or water media. Ananingsih et al. (30) reported that catechins present in tea prevent oxidation in lipophilic and emulsion media. In the present study, the highest antioxidant capacity at the end of frying was detected in the oil with purified $\gamma$-oryzanol (1.4 mM of TEAC per $100 \mathrm{~g}$ of oil) followed by the samples with green tea extract, lycopene and resveratrol extracts (Table 6).

Table 6. Antioxidant capacity of phenolic extracts in oil samples supplemented with antioxidants

\begin{tabular}{cccc}
\hline \multirow{2}{*}{$t /$ day } & \multicolumn{3}{c}{ Antioxidant capacity/(mM TEAC/100 g oil) } \\
\cline { 2 - 4 } & Control & BHA/BHT & GTE \\
\hline 0 & $(3.1 \pm 0.1)^{\mathrm{cA}}$ & $(3.2 \pm 0.1)^{\mathrm{cA}}$ & $(11.0 \pm 0.5)^{\mathrm{aA}}$ \\
1 & $(1.8 \pm 0.1)^{\mathrm{cB}}$ & $(2.2 \pm 0.1)^{\mathrm{cB}}$ & $(5.5 \pm 1.0)^{\mathrm{abB}}$ \\
2 & $(1.2 \pm 0.1)^{\mathrm{cBC}}$ & $(1.3 \pm 0.2)^{\mathrm{cBC}}$ & $(3.2 \pm 0.4)^{\mathrm{aBC}}$ \\
3 & $(0.8 \pm 0.1)^{\mathrm{cCD}}$ & $(0.8 \pm 0.1)^{\mathrm{CCD}}$ & $(2.1 \pm 0.3)^{\mathrm{aC}}$ \\
4 & $(0.5 \pm 0.1)^{\mathrm{bD}}$ & $(0.7 \pm 0.1)^{\mathrm{cCD}}$ & $(1.9 \pm 0.2)^{\mathrm{aC}}$ \\
5 & n.d. & $(0.5 \pm 0.1)^{\mathrm{bD}}$ & $(1.2 \pm 0.1)^{\mathrm{abD}}$ \\
6 & n.d. & n.d. & $(1.1 \pm 0.1)^{\mathrm{bD}}$ \\
7 & n.d. & n.d. & $(0.9 \pm 0.1)^{\mathrm{bD}}$ \\
\hline$t /$ day & LYE & RSV & PGO \\
\hline 0 & $(5.8 \pm 0.5)^{\mathrm{bcA}}$ & $(9.2 \pm 0.6)^{\mathrm{bA}}$ & $(8.7 \pm 0.4)^{\mathrm{bA}}$ \\
1 & $(4.6 \pm 1.6)^{\mathrm{abAB}}$ & $(3.7 \pm 0.2)^{\mathrm{bcB}}$ & $(6.3 \pm 1.6)^{\mathrm{aAB}}$ \\
2 & $(2.5 \pm 0.5)^{\mathrm{abBC}}$ & $(2.1 \pm 0.3)^{\mathrm{abBC}}$ & $(3.2 \pm 0.5)^{\mathrm{aBC}}$ \\
3 & $(1.8 \pm 0.5)^{\mathrm{abBC}}$ & $(1.5 \pm 0.1)^{\mathrm{abCD}}$ & $(2.4 \pm 0.3)^{\mathrm{aC}}$ \\
4 & $(1.5 \pm 0.2)^{\mathrm{abBC}}$ & $(1.2 \pm 0.1)^{\mathrm{abCD}}$ & $(1.8 \pm 0.2)^{\mathrm{aCD}}$ \\
5 & $(1.1 \pm 0.2)^{\mathrm{abC}}$ & $(1.0 \pm 0.2)^{\mathrm{bD}}$ & $(1.8 \pm 0.1)^{\mathrm{aCD}}$ \\
6 & $(1.0 \pm 0.1)^{\mathrm{bC}}$ & $(0.9 \pm 0.1)^{\mathrm{bD}}$ & $(1.7 \pm 0.1)^{\mathrm{aCD}}$ \\
7 & $(0.9 \pm 0.1)^{\mathrm{bC}}$ & $(0.7 \pm 0.1)^{\mathrm{bD}}$ & $(1.4 \pm 0.1)^{\mathrm{aD}}$ \\
\hline
\end{tabular}

All results are mean value \pm standard error (S.E.)

Mean values followed by different lowercase letters in superscript represent significant differences among the measured properties $(\mathrm{p} \leq 0.05)$ in the frying groups

Mean values followed by different capital letters in superscript represent significant differences among the measured properties on a particular frying day $(\mathrm{p} \leq 0.05)$

BHA/BHT=butylated hydroxyanisole/butylated hydroxytoluene mixture, GTE=green tea extract, LYE=purified lycopene, RSV=purified resveratrol, $\mathrm{PGO}=$ purified $\gamma$-oryzanol, n.d.=not detected

\section{Fatty acid composition of the oil}

Distinct differences in fatty acid composition were detected between the control group and experimental groups supplemented with antioxidants (Table 7). It was found that palmitic acid (C16:0) content increased a little during frying, which was confirmed by other researchers $(3,31)$. In addition, stearic (C18:0), arachidic (C20:0) and behenic (C22:0) acid mass fractions were relatively higher in the oil containing antioxidants than in the control oil. As it was indicated, loss of polyunsaturated fatty acids during frying was mainly due to oxidation (4). As can be seen in Table 7, oil supplemented with antioxidants had higher content of oleic (C18:1) than linoleic (C18:2) acid. This increase observed in oleic acid could be a relative increase as a result of the loss of linoleic acid. Frying oil and fried food products can be a source of trans-fatty acids in the daily diet. The formation of trans-fatty acids increased together with the increase in frying time and temperature $(32,33)$. In this study, generally trans-fatty acid content of all samples on the seventh day of frying was higher than that of fresh oil. Formation of trans-fatty acids (g per $100 \mathrm{~g}$ of oil) was the highest in the control group. In addition, statistically significant $(\mathrm{p} \leq 0.05)$ decrease in the levels of linoleic and linolenic (C18:3) acids during frying was observed.

\section{Sterol composition of oil samples}

Phytosterols are triterpene compounds and also minor components in vegetable oil. They lose their biological activity and become oxidized when exposed to air at high temperatures. Phytosterols that contain ethyldiene group at the side chain are capable of delaying polymerization at frying temperatures. In addition, high temperature can lead to the degradation of sterols. Researchers reported campesterol and $\beta$-sitosterol losses of 32 and 94 $\%$, and 33 and $95 \%$ at 100 and $150{ }^{\circ} \mathrm{C}$, respectively. Interestingly, they observed that the losses at $180^{\circ} \mathrm{C}$ were lower than at $150{ }^{\circ} \mathrm{C}(34,35)$. In our previous study (36), the effect of phytostanol mixture addition $(5,10,15$ and $20 \mathrm{~g}$ per $100 \mathrm{~g}$ of oil) into canola oil during frying $\left(180^{\circ} \mathrm{C}, 25 \mathrm{~h}\right)$ was investigated. The results indicated that sensory quality of the fried dough was better when using oil with $5 \%$ phytostanol; however, samples with added $10 \%$ phytostanol had higher contents of free fatty acids and conjugated dienes. It was shown (Table 8) that there was significant decrease in the sterol content during frying (compared with the fresh oil) but the highest sterol content was found in the sample containing purified $\gamma$-oryzanol, indicating protective effect of antioxidants. At the end of frying, there were statistically significant differences $(p \leq 0.05)$ between the total sterol content of the oil samples supplemented with antioxidants.

\section{Sensory evaluation}

All the sensory characteristics (appearance, texture, taste/flavour and odour/aroma) of fried dough evaluated in this study (Table 9) were statistically significantly different $(p \leq 0.05)$ among the experimental groups. It is obvious that fried dough in control group and in oil samples supplemented with antioxidants had different scores for appearance and texture. The amount of oil absorbed by fried dough changed between 3.6 and $9.9 \mathrm{~g}$ per $100 \mathrm{~g}$ of 
Table 7. The fatty acid composition of the fresh peanut oil, control oil and oil samples supplemented with antioxidants obtained on the seventh day of frying

\begin{tabular}{|c|c|c|c|c|c|c|c|}
\hline \multirow{2}{*}{$\begin{array}{l}\text { Composition of } \\
\text { fatty acids }\end{array}$} & \multicolumn{7}{|c|}{$w($ fatty acid $) /(\mathrm{g} / 100 \mathrm{~g}$ oil $)$} \\
\hline & $\begin{array}{c}\text { Fresh } \\
\text { peanut oil }\end{array}$ & Control & $\mathrm{BHA} / \mathrm{BHT}$ & GTE & LYE & RSV & PGO \\
\hline $\mathrm{C} 8: 0(\mathrm{p}=0.000)$ & n.d. & $(0.15 \pm 0.07)^{\mathrm{B}}$ & $(0.43 \pm 0.04)^{\mathrm{A}}$ & $(0.47 \pm 0.04)^{\mathrm{A}}$ & $(0.44 \pm 0.02)^{\mathrm{A}}$ & $(0.40 \pm 0.02)^{\mathrm{A}}$ & $(0.44 \pm 0.01)^{\mathrm{A}}$ \\
\hline $\mathrm{C} 16: 0(\mathrm{p}=0.000)$ & $(9.7 \pm 0.10)^{\mathrm{D}}$ & $(10.8 \pm 0.1)^{\mathrm{C}}$ & $(12.5 \pm 0.1)^{\mathrm{AB}}$ & $(13.2 \pm 0.1)^{\mathrm{A}}$ & $(13.1 \pm 0.1)^{\mathrm{A}}$ & $(13.2 \pm 0.1)^{\mathrm{A}}$ & $(13.1 \pm 0.1)^{\mathrm{A}}$ \\
\hline $\mathrm{C} 16: 1(\mathrm{p}=0.000)$ & $(0.08 \pm 0.02)^{\mathrm{A}}$ & $(0.07 \pm 0.01)^{\mathrm{A}}$ & $(0.08 \pm 0.02)^{\mathrm{A}}$ & n.d. & n.d. & n.d. & n.d. \\
\hline $\mathrm{C} 18: 0(\mathrm{p}=0.000)$ & $(3.3 \pm 0.1)^{\mathrm{B}}$ & $(3.8 \pm 0.1)^{\mathrm{B}}$ & $(4.3 \pm 0.1)^{\mathrm{A}}$ & $(4.5 \pm 0.1)^{\mathrm{A}}$ & $(4.5 \pm 0.1)^{\mathrm{A}}$ & $(4.5 \pm 0.1)^{\mathrm{A}}$ & $(4.4 \pm 0.1)^{\mathrm{A}}$ \\
\hline $\mathrm{C} 18: 1(\mathrm{cis})(\mathrm{p}=0.000)$ & $(47.9 \pm 0.4)^{\mathrm{B}}$ & $(50.2 \pm 0.4)^{\mathrm{AB}}$ & $(53.0 \pm 0.1)^{\mathrm{A}}$ & $(53.5 \pm 0.4)^{\mathrm{A}}$ & $(53.6 \pm 0.4)^{\mathrm{A}}$ & $(53.5 \pm 0.3)^{\mathrm{A}}$ & $(53.4 \pm 0.2)^{\mathrm{A}}$ \\
\hline $\mathrm{C} 18: 1($ trans $)(\mathrm{p}=0.000)$ & $(0.05 \pm 0.01)^{\mathrm{B}}$ & $(0.9 \pm 0.1)^{\mathrm{A}}$ & $(0.8 \pm 0.1)^{\mathrm{AB}}$ & $(0.8 \pm 0.1)^{\mathrm{AB}}$ & $(0.8 \pm 0.2)^{\mathrm{AB}}$ & $(0.8 \pm 0.2)^{\mathrm{AB}}$ & $(0.8 \pm 0.1)^{\mathrm{AB}}$ \\
\hline $\mathrm{C} 18: 2($ cis $)(\mathrm{p}=0.000)$ & $(30.7 \pm 0.1)^{\mathrm{A}}$ & $(25.6 \pm 0.1)^{\mathrm{B}}$ & $(19.3 \pm 0.1)^{\mathrm{C}}$ & $(18.2 \pm 0.1)^{\mathrm{D}}$ & $(18.2 \pm 0.1)^{\mathrm{D}}$ & $(17.8 \pm 0.1)^{\mathrm{E}}$ & $(17.5 \pm 0.1)^{\mathrm{E}}$ \\
\hline $\mathrm{C} 18: 2($ trans $)(\mathrm{p}=0.000)$ & $(0.06 \pm 0.01)^{\mathrm{C}}$ & $(0.15 \pm 0.03)^{\mathrm{A}}$ & $(0.13 \pm 0.03)^{\mathrm{AB}}$ & $(0.12 \pm 0.01)^{\mathrm{AB}}$ & $(0.12 \pm 0.01)^{\mathrm{AB}}$ & $(0.10 \pm 0.01)^{\mathrm{B}}$ & $(0.11 \pm 0.01)^{\mathrm{B}}$ \\
\hline $\mathrm{C} 18: 3(\mathrm{p}=0.000)$ & $(0.30 \pm 0.01)^{\mathrm{A}}$ & $(0.20 \pm 0.01)^{\mathrm{AB}}$ & $(0.18 \pm 0.01)^{\mathrm{BC}}$ & $(0.10 \pm 0.02)^{\mathrm{D}}$ & $(0.10 \pm 0.01)^{\mathrm{D}}$ & $(0.08 \pm 0.01)^{\mathrm{E}}$ & $(0.14 \pm 0.04)^{\mathrm{CD}}$ \\
\hline $\mathrm{C} 20: 0(\mathrm{p}=0.000)$ & $(1.5 \pm 0.1)^{\mathrm{B}}$ & $(1.6 \pm 0.1)^{\mathrm{B}}$ & $(1.7 \pm 0.1)^{\mathrm{AB}}$ & $(1.8 \pm 0.1)^{\mathrm{A}}$ & $(1.8 \pm 0.1)^{\mathrm{A}}$ & $(1.8 \pm 0.1)^{\mathrm{A}}$ & $(1.8 \pm 0.1)^{\mathrm{A}}$ \\
\hline $\mathrm{C} 20: 1(\mathrm{p}=0.000)$ & $(1.2 \pm 0.1)^{\mathrm{B}}$ & $(1.2 \pm 0.1)^{\mathrm{B}}$ & $(1.3 \pm 0.1)^{\mathrm{A}}$ & $(1.3 \pm 0.1)^{\mathrm{A}}$ & $(1.3 \pm 0.1)^{\mathrm{A}}$ & $(1.3 \pm 0.2)^{\mathrm{A}}$ & $(1.3 \pm 0.2)^{\mathrm{A}}$ \\
\hline $\mathrm{C} 20: 3(\mathrm{p}=0.017)$ & $(0.11 \pm 0.01)^{\mathrm{AB}}$ & $(0.10 \pm 0.01)^{\mathrm{AB}}$ & $(0.12 \pm 0.01)^{\mathrm{A}}$ & $(0.08 \pm 0.01)^{\mathrm{B}}$ & $(0.11 \pm 0.01)^{\mathrm{AB}}$ & $(0.09 \pm 0.01)^{\mathrm{B}}$ & $(0.09 \pm 0.01)^{\mathrm{B}}$ \\
\hline $\mathrm{C} 20: 5(\mathrm{p}=0.000)$ & $(1.3 \pm 0.1)^{\mathrm{B}}$ & $(1.5 \pm 0.2)^{\mathrm{B}}$ & $(1.7 \pm 0.1)^{\mathrm{AB}}$ & $(1.7 \pm 0.1)^{\mathrm{AB}}$ & $(1.7 \pm 0.1)^{\mathrm{AB}}$ & $(1.8 \pm 0.2)^{\mathrm{A}}$ & $(1.8 \pm 0.2)^{\mathrm{A}}$ \\
\hline $\mathrm{C} 22: 0(\mathrm{p}=0.000)$ & $(3.2 \pm 0.1)^{\mathrm{B}}$ & $(3.4 \pm 0.1)^{\mathrm{B}}$ & $(4.1 \pm 0.1)^{\mathrm{A}}$ & $(4.2 \pm 0.1)^{\mathrm{A}}$ & $(4.1 \pm 0.1)^{\mathrm{A}}$ & $(4.2 \pm 0.1)^{\mathrm{A}}$ & $(4.2 \pm 0.1)^{\mathrm{A}}$ \\
\hline
\end{tabular}

All results are mean value \pm standard deviation (S.D.). Mean values followed by different capital letters in superscript represent significant differences among the measured properties $(\mathrm{p} \leq 0.05)$ in the frying groups. BHA/BHT=butylated hydroxyanisole/butylated hydroxytoluene mixture, GTE=green tea extract, LYE=purified lycopene, RSV=purified resveratrol, PGO=purified $\gamma$-oryzanol, n.d.=not detected

Table 8. The sterol composition of the fresh peanut oil and oil samples supplemented with antioxidants obtained on the seventh day of frying

\begin{tabular}{|c|c|c|c|c|c|}
\hline \multirow{2}{*}{ Composition of sterols } & \multicolumn{5}{|c|}{$w /(\mathrm{mg} / 100 \mathrm{~g}$ oil $)$} \\
\hline & Fresh peanut oil & GTE & LYE & RSV & PGO \\
\hline Campesterol $(\mathrm{p}=0.000)$ & $(16.3 \pm 0.1)^{\mathrm{A}}$ & $(2.8 \pm 0.1)^{\mathrm{B}}$ & $(2.1 \pm 0.1)^{\mathrm{BC}}$ & $(1.5 \pm 0.1)^{\mathrm{C}}$ & $(2.4 \pm 0.1)^{\mathrm{BC}}$ \\
\hline Stigmasterol $(\mathrm{p}=0.008)$ & $(7.4 \pm 0.1)^{\mathrm{A}}$ & $(1.0 \pm 0.1)^{\mathrm{B}}$ & $(0.7 \pm 0.1)^{\mathrm{C}}$ & $(0.5 \pm 0.1)^{\mathrm{D}}$ & $(0.7 \pm 0.1)^{\mathrm{C}}$ \\
\hline$\beta$-Sitosterol $(p=0.004)$ & $(67.6 \pm 0.1)^{\mathrm{A}}$ & $(8.3 \pm 0.1)^{\mathrm{B}}$ & $(7.1 \pm 0.1)^{\mathrm{D}}$ & $(7.8 \pm 0.1)^{\mathrm{C}}$ & $(7.2 \pm 0.1)^{\mathrm{D}}$ \\
\hline Sitostanol $(\mathrm{p}=0.000)$ & $(1.3 \pm 0.1)^{\mathrm{A}}$ & $(0.2 \pm 0.1)^{\mathrm{E}}$ & $(0.7 \pm 0.1)^{\mathrm{B}}$ & $(0.4 \pm 0.1)^{\mathrm{D}}$ & $(0.5 \pm 0.1)^{\mathrm{C}}$ \\
\hline$\Delta$-7-Avenasterol $(\mathrm{p}=0.000)$ & $(1.9 \pm 0.1)^{\mathrm{A}}$ & $(0.2 \pm 0.1)^{\mathrm{C}}$ & $(0.2 \pm 0.1)^{\mathrm{C}}$ & $(0.2 \pm 0.1)^{\mathrm{C}}$ & $(1.4 \pm 0.1)^{\mathrm{B}}$ \\
\hline$\Delta-5,24$-Stigmastadienol $(\mathrm{p}=0.000)$ & $(0.8 \pm 0.1)^{\mathrm{C}}$ & $(0.1 \pm 0.0)^{\mathrm{D}}$ & $(0.1 \pm 0.0)^{\mathrm{D}}$ & $(0.9 \pm 0.1)^{\mathrm{B}}$ & $(1.7 \pm 0.1)^{\mathrm{A}}$ \\
\hline Total sterol & $(95.3 \pm 0.6)^{\mathrm{A}}$ & $(12.6 \pm 0.5)^{\mathrm{BC}}$ & $(10.9 \pm 0.5)^{\mathrm{C}}$ & $(11.3 \pm 0.6)^{\mathrm{C}}$ & $(13.9 \pm 0.6)^{\mathrm{B}}$ \\
\hline
\end{tabular}

All results are mean value \pm standard deviation (S.D.). Mean values followed by different capital letters in superscript represent significant differences among the measured properties $(\mathrm{p} \leq 0.05)$ in the frying groups. GTE=green tea extract, LYE=purified lycopene, RSV=purified resveratrol, $\mathrm{PGO}=$ purified $\gamma$-oryzanol

Table 9. Sensory data collected for the fried dough at the end of the fourth, fifth and sixth frying day by the hedonic scale

\begin{tabular}{lcccc}
\hline Oil sample & Appearance $(\mathrm{p}=0.001)$ & Texture $(\mathrm{p}=0.001)$ & Taste/flavour $(\mathrm{p}=0.001)$ & Odour/aroma $(\mathrm{p}=0.001)$ \\
\hline Control & $(3.1 \pm 0.1)^{\mathrm{A}}$ & $(2.9 \pm 0.1)^{\mathrm{A}}$ & $(2.5 \pm 0.1)^{\mathrm{B}}$ & $(2.7 \pm 0.1)^{\mathrm{BC}}$ \\
Supplemented with BHA/BHT & $(2.6 \pm 0.1)^{\mathrm{C}}$ & $(2.0 \pm 0.9)^{\mathrm{B}}$ & $(2.3 \pm 0.1)^{\mathrm{C}}$ & $(2.9 \pm 0.4)^{\mathrm{AB}}$ \\
Supplemented with GTE & $(3.0 \pm 0.1)^{\mathrm{A}}$ & $(2.0 \pm 0.1)^{\mathrm{B}}$ & $(2.4 \pm 0.1)^{\mathrm{BC}}$ & $(2.5 \pm 0.1)^{\mathrm{C}}$ \\
Supplemented with LYE & $(2.9 \pm 0.1)^{\mathrm{AB}}$ & $(1.9 \pm 0.1)^{\mathrm{C}}$ & $(2.4 \pm 0.1)^{\mathrm{BC}}$ & $(2.6 \pm 0.1)^{\mathrm{C}}$ \\
Supplemented with RSV & $(2.8 \pm 0.1)^{\mathrm{BC}}$ & $(2.4 \pm 0.1)^{\mathrm{AB}}$ & $(2.5 \pm 0.1)^{\mathrm{B}}$ & $(2.7 \pm 0.1)^{\mathrm{BC}}$ \\
Supplemented with PGO & $(3.6 \pm 0.1)^{\mathrm{A}}$ & $(2.9 \pm 0.1)^{\mathrm{A}}$ & $(3.0 \pm 0.1)^{\mathrm{A}}$ & $(3.1 \pm 0.1)^{\mathrm{A}}$ \\
\hline
\end{tabular}

All results are mean value \pm standard deviation (S.D.). Mean values followed by different capital letters in superscript represent significant differences among the measured properties $(\mathrm{p} \leq 0.05)$ in the frying groups. The mean scores of sensory attributes collected by the hedonic scale ( $N=100$ subjects) were calculated: $1=$ dislike extremely, $2=$ dislike moderately, $3=$ neither like nor dislike, $4=$ like moderately and $5=$ like extremely. BHA/BHT=butylated hydroxyanisole/butylated hydroxytoluene mixture, GTE=green tea extract, LYE=purified lycopene, RSV=purified resveratrol, PGO=purified $\gamma$-oryzanol 
oil (data not shown); moreover, synthetic and natural antioxidant supplementation did not have significant effect on the amount of fat absorbed by the fried dough. Suárez et al. (37) investigated the sensory characteristics of coated and uncoated fried dough at selected time and temperature conditions. The optimum frying conditions were determined to be $160{ }^{\circ} \mathrm{C}$ for $12 \mathrm{~min}$, and there were no differences in sensory properties (colour, flavour, texture and overall appearance) among all dough samples. In the present study, the results revealed that the dough fried in oil supplemented with natural antioxidants generally had higher sensory scores than the dough fried in oil containing synthetic antioxidants, except for texture and odour/ aroma properties (Table 9). Hence, it is concluded that the addition of natural antioxidant extracts to frying oil can produce more acceptable products compared to the control group.

\section{Conclusion}

Frying oil supplemented with 0.05 to $4.32 \mathrm{~g}$ of plant phenolic extracts exhibited preventive effects against thermo-oxidative degradation and provided desired sensory characteristics to the fried dough. Especially purified $\gamma$-oryzanol extract yielded much better results. Public health considerations are urging the use of more natural food and food additives. Hence, natural antioxidants can successfully replace synthetic additives in frying oil. Since natural antioxidants gave better protection to oil under the investigated frying conditions than the control (oil without antioxidants) and oil containing synthetic antioxidants, the mechanism responsible for the beneficial effects of the natural antioxidants may be elucidated with further studies.

\section{Acknowledgements}

This study was funded by the Scientific Research Projects Office of Çanakkale Onsekiz Mart University, Çanakkale,Turkey (Project no: BAP-2010/153). The authors are grateful to Helvacizade Food Pharma \& Chemicals (Konya, Turkey) for the refined peanut oil gift for this study. All authors declare no conflict of interest and alone are responsible for the content and writing of this article.

\section{References}

1. Kochhar SP. The composition of frying oils. In: Rossell JB, editor. Frying improving quality. Boca Raton, USA: CRC Press; 2001. pp. 87-114.

2. Blumenthal MM. A new look at the chemistry and physics of deep-fat frying. Food Tech. 1991;45:68-71.

3. Romero A, Cuesta C, Sánchez-Muniz FJ. Effect of oil replenishment during deep-fat frying of frozen foods in sunflower oil and high-oleic acid sunflower oil. J Am Oil Chem Soc. 1998;75:161-7. http://dx.doi.org/10.1007/s11746-998-0028-5

4. Choe E, Min DB. Chemistry of deep-fat frying oils. J Food Sci. 2007;72:77-84. http://dx.doi.org/10.1111/j.1750-3841.2007.00352.x

5. Aladedunye FA, Przybylski R. Protection of oil during frying: a comparative study. Eur J Lipid Sci Tech. 2009;111:893901.

http://dx.doi.org/10.1002/ejlt.200900020
6. Aydeniz B, Yulmaz E. Enrichment of frying oils with plant phenolic extracts to extend the usage life. Eur J Lipid Sci Tech. 2012;114:933-41.

http://dx.doi.org/10.1002/ejlt.201100228

7. Rababah TM, Feng H, Yang W, Yücel S. Fortification of potato chips with natural plant extracts to enhance their sensory properties and storage stability. J Am Oil Chem Soc. 2012;89:1419-25.

http://dx.doi.org/10.1007/s11746-012-2037-7

8. Koh SP, Arifin N, Tan CP, Yusoff MSA, Long K, Lai OM. Deep frying performance of enzymatically synthesized palm-based medium- and long-chain triacylglycerols (MLCT) oil blends. Food Bioprocess Tech. 2008;4:124-35. http://dx.doi.org/10.1007/s11947-008-0138-y

9. Sanders TH. Groundnut (peanut) oil. In: Gunstone FD, editor. Vegetable oils in food technology: composition, properties and uses. Hoboken, NY, USA: Wiley Blackwell; 2002. pp. 231-2.

10. Perva-Uzunalic A, Skerget M, Knez Z, Weinreich B, Otto F, Grüner S. Extraction of active ingredients from green tea (Camellia sinensis): Extraction efficiency of major catechins and caffeine. Food Chem. 2006;96:597-605. http://dx.doi.org/10.1016/j.foodchem.2005.03.015

11. ISO 14502-2:2005. Determination of substances characteristic of green and black tea - Part 2: Content of catechins in green tea method using high-performance liquid chromatography. Geneva, Switzerland: International Organization for Standardization (ISO); 2006.

12. Chotimarkorn C, Benjakul S, Silalai N. Antioxidative effects of rice bran extracts on refined tuna oil during storage. Food Res Int. 2008;41:616-22. http://dx.doi.org/10.1016/j.foodres.2008.04.002

13. Re R, Pellegrini N, Proteggente A, Pannala A, Yang M, RiceEvans C. Antioxidant activity applying an improved ABTS radical cation decolorization assay. Free Radical Biol Med. 1999;26:1231-7. http://dx.doi.org/10.1016/S0891-5849(98)00315-3

14. AOCS Official Method Ca 5a-40. Free fatty acids. In: Firestone D, editor. Official Methods and Recommended Practices of the American Oil Chemists' Society (AOCS). Champaign, IL, USA: AOCS Press; 1998.

15. AOCS Official Method Ti 1a-64. Spectrophotometric determination of conjugated dienoic acid. In: Firestone D, editor. Official Methods and Recommended Practices of the American Oil Chemists' Society (AOCS). Champaign, IL, USA: AOCS Press; 1998.

16. AOCS Official Method Cd 20-91. Determination of polar compounds in frying fats. In: Firestone D. editor. Official Methods and Recommended Practices of the American Oil Chemists' Society (AOCS). Champaign, IL, USA: AOCS Press; 1998.

17. AOCS Official Method Ce 2-66. Preparation of methyl esters of long-chain fatty acids from sampling and analysis of commercial fats and oils. In: Firestone D, editor. Official Methods and Recommended Practices of the American Oil Chemists' Society (AOCS). Champaign, IL, USA: AOCS Press; 1998.

18. AOCS method Ce 1-62. Fatty acid analysis by gas chromatograph. In: Firestone D, editor. Official Methods and Recommended Practices of the American Oil Chemists' Society (AOCS). Champaign, IL, USA: AOCS Press; 1998.

19. ISO 12228:1999. Animal and vegetable fats and oils - Determination of individual and total sterols contents - gas chromatographic method. Geneva, Switzerland: International Organization for Standardization (ISO); 1999.

20. ISO 6658:2005. Sensory analysis - Methodology - General guidance. Geneva, Switzerland: International Organization for Standardization (ISO); 2005. 
21. MINITAB (Minitab Statistical Software System), v. 16.1.1. Minitab Inc., State College, PA, USA; 2010. Available from: http://www.minitab.com.

22. Lolos M, Oreopoulou V, Tzia C. Oxidative stability of potato chips: effect of frying oil type, temperature and antioxidants. J Sci Food Agr. 1999;79:1524-8. http://dx.doi.org/10.1002/(SICI)1097-0010(199908)79:11<1524: :AID-JSFA401>3.0.CO;2-H

23. Smith SA, King RE, Min DB. Oxidative and thermal stabilities of genetically modified high oleic sunflower oil. Food Chem. 2007;102:1208-13.

http://dx.doi.org/10.1016/j.foodchem.2006.06.058

24. Abdulkarim SM, Long K, Lai OM, Muhammad SKS, Ghazali HM. Frying quality and stability of high-oleic Moringa oleifera seed oil in comparison with other vegetable oils. Food Chem. 2007;105:1382-9. http://dx.doi.org/10.1016/j.foodchem.2007.05.013

25. Lee J, Lee S, Lee H, Park K, Choe E. Spinach (Spinacia oleracea) powder as a natural food-grade antioxidant in deep-fatfried products. J Agric Food Chem. 2002;50:5664-9. http://dx.doi.org/10.1021/jf011618a

26. Turkish Food Codex No: 2007/41. Official notification of the control criteria of frying Fats/Oils. Ankara, Turkey: Turkish Food Codex; 2007.

27. Chen ZY, Xhu QY, Tsang D, Huang Y. Degradation of green tea catechins in tea drinks. J Agric Food Chem. 2001;49:477-82. http://dx.doi.org/10.1021/jf000877h

28. Rusak G, Komes D, Likić S, Horžić D, Kovač M. Phenolic content and antioxidative capacity of green and white tea extracts depending on extraction conditions and the solvent used. Food Chem. 2008;110:852-8. http://dx.doi.org/10.1016/j.foodchem.2008.02.072

29. Konsoula Z, Liakopoulou-Kyriakides M. Effect of endogenous antioxidants of sesame seeds and sesame oil to the thermal stability of edible vegetable oils. LWT - Food Sci Technol. 2010;43:1379-86. http://dx.doi.org/10.1016/j.1wt.2010.04.016
30. Ananingsih VK, Sharma A, Zhou W. Green tea catechins during food processing and storage: A review on stability and detection. Food Res Int. 2013;50:469-79.

http://dx.doi.org/10.1016/j.foodres.2011.03.004

31. Sebedio JL, Bonpunt A, Grandgirard A, Prevost J. Deep fat frying of frozen prefried french fries: Influence of the amount of linolenic acid in the frying medium. J Agric Food Chem. 1990;38:1862-7. http://dx.doi.org/10.1021/jf00099a017

32. Ovesen L, Leth T, Hansen K. Fatty acid composition and contents of trans monounsaturated fatty acids in frying fats, and in margarines and shortenings marketed in Denmark. J Am Oil Chem Soc. 1998;75:1079-83. http://dx.doi.org/10.1007/s11746-998-0116-6

33. van Poppel G, van Erp-Baart MA, Leth T, Gevers E, Van Amelsvoort J, Lanzmann-Petithory D, et al. Trans fatty acids in foods in Europe: the transfair study. J Food Compos Anal. 1998;11:112-36. http://dx.doi.org/10.1006/jfca.1998.0568

34. Oehrl LL, Hansen AP, Rohrer CA, Fener GP, Boyd LC. Oxidation of phytosterols in a test food system. J Am Oil Chem Soc. 2001;78:1073-8. http://dx.doi.org/10.1007/s11746-001-0391-z

35. Lampi AM, Juntunen L, Toivo J, Piironen V. Determination of thermo-oxidation products of plant sterols. J Chromatogr B. 2002;777:83-92. http://dx.doi.org/10.1016/S1570-0232(02)00094-6

36. Aydeniz B, Yilmaz E. Phytostanol supplementation through frying dough in enriched canola oil. J Am Oil Chem Soc. 2013;90:687-94. http://dx.doi.org/10.1007/s11746-012-2201-0

37. Suárez RB, Campañone LA, García MA, Zaritzky NE. Comparison of the deep frying process in coated and uncoated dough systems. J Food Eng. 2008;84:383-93. http://dx.doi.org/10.1016/j.jfoodeng.2007.05.031 